\title{
Metallothioneins and copper metabolism are candidate therapeutic targets in Huntington's disease
}

\author{
S L Hands ${ }^{\mathrm{a}}$, R Mason ${ }^{\mathrm{b}}$, M U Sajjad ${ }^{\mathrm{a}}$, F Giorgini $^{\mathrm{b}}$, A Wyttenbach $^{\mathrm{a}}$ \\ ${ }^{\text {a }}$ Neuroscience Group, School of Biological Sciences, University of Southampton, \\ Basset Crescent East, Southampton, UK \\ ${ }^{\mathrm{b}}$ Department of Genetics, University of Leicester, Leicester, UK \\ ${ }^{1}$ to whom correspondence should be addressed (email aw3@soton.ac.uk)
}

\begin{abstract}
Huntington's disease (HD) is caused by a polyglutamine (polyQ) expansion in the huntingtin protein, which leads to protein misfolding and aggregation of this protein. Abnormal copper accumulation in the HD brain was first reported more than 15 years ago. Recent findings show that copper regulatory genes are induced during HD and copper binds to an N-terminal fragment of huntingtin supporting the involvement of abnormal copper metabolism in HD. Here we show that in vitro copper accelerates the fibrillisation of an N-terminal fragment of huntingtin with an expanded polyQ stretch (httExon1). As we found that copper also increases polyQ aggregation and toxicity in mammalian cells expressing httExon1, we further investigated whether overexpression of genes involved in copper metabolism, notably metallothioneins (MTs) known to bind copper, protect against httExon1 toxicity. Using a yeast model of HD, we show that overexpression of several genes involved in copper metabolism reduces polyQ mediated toxicity. Overexpression of MT-3 in mammalian cells significantly reduced polyQ aggregation and toxicity. We propose that copperbinding-and/or chaperoning proteins, especially MTs, are potential therapeutic targets for HD.
\end{abstract}




\section{Introduction}

Huntington's disease (HD) is a neurodegenerative disorder caused by an abnormal polyglutamine (polyQ) expansion in the $350 \mathrm{kDa}$ protein, huntingtin (htt). HD is associated with intracellular aggregates (or inclusion bodies, IB) and neuronal loss, predominantly occurring in the striatum and cerebral cortex. Posttranslational modifications and cleavage of htt occur in vivo and the resulting $\mathrm{N}$-terminal htt fragments containing the polyQ stretch are prone to misfolding and aggregation [1]. This misfolding and/or aggregation likely leads to a toxic gain of function, although loss of normal htt function, which has been implicated to participate in a variety of cellular functions, may also play a role during disease. Many cellular dysfunctions have been identified that could participate in the disease process including impaired transcription, mitochondrial abnormalities, dysregulation of the cellular redoxhomeostasis and deficits in protein degradation pathways, axonal transport and synaptic function (for a recent review see [2]).

Both iron and copper accumulate in the central nervous system (CNS) of HD mouse models and in the HD brain [3, 4] and could play a role in the above-mentioned cellular alterations that occur in HD. Indeed, several recent findings point to the importance of copper in HD. Clioquinol, a copper/iron-chelator, significantly delays neuropathology in HD mice [5] and N-terminal htt binds copper in vitro and in vivo [4]. Htt has also been shown to reduce copper (II) and increase aggregation of the full-length wild-type (non-expanded) htt protein of mice [4]. The reduction of copper and concomitant increase in oligomerisation has also been demonstrated for betaamyloid and is suggested to play a role in the pathogenesis of Alzheimer's Disease [6, 7]. Copper is crucial for electron transfer reactions in a number of enzymes involved in activities such as antioxidant defence and neurotransmitter biosynthesis. Despite this essential requirement for copper, an excess of this heavy metal is toxic, primarily due to its reactivity with molecular oxygen which leads to formation of reactive oxygen species (ROS). Therefore the transport and compartmentalisation of copper is highly regulated, involving copper transporters and chaperones (see Table 1). By examining published gene expression data from HD cell and mouse models and human HD brain tissue we found that copper-binding/chaperoning proteins, including metallothioneins (MTs), were consistently up-regulated (Table 1). This could reflect a protective response against increased copper and ROS and/or a disruption of copper homeostasis more generally. This observation led us to test whether overexpression of copper-regulating genes in yeast and mammalian cell models of HD reduce htt toxicity. Because oligomerisation and the production of amyloid-like structures of $\mathrm{N}$ terminal htt has been tightly linked to cellular toxicity [8-11] we have also investigated whether copper modulates the formation of such protein assemblies using atomic force microscopy and biochemical assays and tested if increased expression of copper-binding proteins reduces htt aggregation.

\section{Materials and methods}

\section{Protein purification and Atomic force microscopy}

pGEX-HD53/20Q plasmids were kindly provided by Paul Muchowski (Gladstone Institute of Neurological Disease, University of California, San Francisco) and httEx1-GST was prepared as described previously $[12,13]$. The integrity of the protein was validated using SDS-PAGE. The protein was dialysed in $20 \mathrm{mM}$ Tris- $\mathrm{HCl}$ 
pH8, 150mM NaCl, 0.1mM EDTA, 5\% glycerol. Freshly prepared protein samples were used for each experiment performed at $4^{\circ} \mathrm{C} .10 \mu \mathrm{M} \mathrm{CuCl}_{2}$ was added prior to the addition of PreScission protease (GE Healthcare 2 units $/ 100 \mu$ g protein) to $50 \mu \mathrm{M}$ GSThtt-Q20 or -Q53 to initiate GST cleavage. 24 hours after addition of PreScission protease and/or $\mathrm{CuCl}_{2}, 5 \mu \mathrm{l}(12 \mu \mathrm{g}$ protein) of the reaction was spotted onto a freshly cleaved mica disc (Agar Scientific) incubated for 2 minutes and then rinsed with $200 \mu \mathrm{l}$ ultrapure water and dried with compressed air. The samples were imaged in air with a digital multimode Nanoscope III AFM (www.veeco.com) operating in tapping mode with an uncoated silicon tip (FM-W, Nanoworld Innovative Technologies, Switzerland).

\section{Cell culture, DNA transfection and Adenovirus infection}

HeLa cells (Sigma) were grown in 4500mg/ml DMEM (Sigma) with 100 units $/ \mathrm{ml}$ penicillin/streptomycin, $2 \mathrm{mM} \mathrm{L}$-glutamine, $1 \mathrm{mM}$ sodium pyruvate, $10 \% \mathrm{FBS}$ at $37^{\circ} \mathrm{C}$, $10 \% \mathrm{CO}_{2}$. For transfection, $150000 \mathrm{HeLa}$ cells per well were plated in 6 well plates $/ 35 \mathrm{~mm}$ dishes and exposed to $2 \mu \mathrm{g}$ of human MT3 DNA (Origene, SC123646) and $4 \mu 1$ lipofectamine (Invitrogen) per well for 5 hours ( 24 hours after seeding) in serum-free medium (OPTI-MEM, Invitrogen), after which culture medium was added. 24 hours later cells were trypsinised and re-plated in 96 well plates. Alternatively cells were treated with $\mathrm{CuCl}_{2}$ or clioquinol for 24 hours in 6 well plates before being re-plated into 96 well plates. Before re-plating, equal numbers of cells were infected in suspension at a multiplicity of infection (MOI) of 10 with an adenovirus expressing httEx 1 containing either 25 or 97 glutamines fused to monomeric red fluorescent protein (mRFP) at the httExl C-terminus. Then cells were cultured for a further 48 hours in the presence/absence of $\mathrm{CuCl}_{2}$ or clioquinol where appropriate after which an MTS assay was performed according to standard protocols (Promega) using a FLUOStar OPTIMA plate-reader (BMG Labtech) at an absorbance wavelength of $490 \mathrm{~nm}$. Cells were fixed subsequently for IB analysis. Overexpression of MT3 was verified by western blotting (data not shown).

\section{Dot blot and Western Blot analysis}

Cell lysis, SDS-PAGE, preparation of samples for dot blots and Western Blots were performed as described previously [14]. Dot blot samples, normalised for total protein content, were filtered on a Bio-Rad dot blot filtration unit through a cellulose acetate membrane with a $0.2 \mu \mathrm{m}$ pore size (Macherey-Nagel, Germany) that was preequilibrated with $2 \%$ SDS. HttEx 1 was detected using a sheep anti-httEx1 antibody at a concentration of 1:6000 (S830, a kind gift from Gillian Bates, Kings College, London) followed by a secondary anti-sheep HRP antibody and ECL detection (Amersham). MT-3 was detected on a Western blot using an anti-mouse MT3 antibody (MO1, Abnova, Taiwan), followed by a secondary anti-mouse HRP antibody and ECL detection.

Overexpression of copper-modulating genes in yeast

Yeast strains containing plasmids for the overexpression of selected genes were obtained from the Yeast ORF Collection (Open Biosystems). The relevant yeast strains were grown overnight in 96 well plates containing $100 \mu 1$ of selective media supplemented with $2 \%$ glucose per well and transformed with either p425GALLhtt25Q-GFP or p425GALL-htt103Q-GFP using a high throughput transformation method [15]. The constructs p425GALL-htt25Q-GFP and p425GALL-htt103Q-GFP were generated by amplifying the huntingtin constructs from pYES2-htt25Q-GFP and 
pYES2-htt103Q-GFP [16] and cloning them into the SpeI and XhoI sites of p425GALL [17]. Both htt103Q and htt25Q are galactose (GAL)-inducible, FLAGand GFP-tagged constructs encoding the first 17 amino acids of htt fused to a polyQ tract. Transformants were grown to stationary phase selective media containing $2 \%$ glucose, serial diluted, and spotted onto selective media supplemented with either $2 \%$ glucose or $2 \%$ galactose and $2 \%$ raffinose. Plates were incubated at $30^{\circ} \mathrm{C}$ for $3-5$ days and yeast strains scored for growth.

\section{Statistical analysis}

Pairwise comparisons were conducted using two-tailed Student's t test and 95\% (*) or $99 \%(* *)$ confidence intervals were used for calculating significance. The number of experiments performed for each result is indicated in the figure legend.

\section{Results}

We used an in vitro model of huntingtin aggregation involving purification of a GST fusion protein of exon 1 of htt (httEx1) followed by cleavage of the GST tag, which induces a time-dependent aggregation of httEx1 $[8,18]$. Cleavage of the GST moiety from httEx1-Q20 did not lead to any detectable aggregation, but imaging of samples of httEx1-Q53 by atomic force microscopy (AFM) revealed amyloid-like fibrillar structures (Figure1A). Addition of $10 \mu \mathrm{M} \mathrm{CuCl}_{2}$ significantly accelerated the production of httEx1 fibrillar structures (Figure 1A). An increase in aggregation due to addition of $\mathrm{CuCl}_{2}$ to purified httEx1-Q53 was also demonstrated using a filter trap assay, which detects SDS-insoluble material produced by httEx1 (Figure 1B).

Due to the observed effect of copper on aggregation of httEx1 protein in vitro, we hypothesised that alterations in copper metabolism would affect aggregation and toxicity induced by expression of httEx1 in vivo. Therefore we tested the ability of overexpression of several yeast genes known to be involved in copper homeostasis to rescue httEx1-mediated toxicity (see Table 1). Figure 2 shows that all seven copper binding genes tested provided some degree of rescue against expanded polyQ toxicity. Because one of the most effective genes in rescuing toxicity was $C R S 5$, a yeast homolog of metallothionein (MT), we chose this protein to test its effects on polyQ aggregation and toxicity in a mammalian cell culture model of httEx1.

We first established that increased copper concentrations also increased httEx1 aggregation in vivo and whether clioquinol, as shown previously [5], was able to reduce aggregation. Equal expression and transgene integrity of httEx1-Q25/97 fused to mRFP was verified by Western Blotting (data not shown). Figure 3A shows that whilst additional copper enhances aggregation of HttEx1-Q97, clioquinol reduces aggregation of HttEx1-Q97 in a dose dependent manner. Copper similarly increased aggregation in rat pheochromocytoma cells (PC12) expressing httEx1-Q97 (data not shown). Copper did not induce polyQ aggregation of httEx1-Q25 which does not normally aggregate when overexpressed at similar levels to httEx1 with a polyQ expansion [14, 19-22]. Clioquinol reduced httEx 1 toxicity and copper increased toxicity in both httEx1-Q25 and Q97 expressing cells (at the concentrations of 10 and $100 \mu \mathrm{M}$ tested) (data not shown). We next overexpressed human MT3 DNA for 24 hours before infection with the httEx1 adenoviruses. We chose MT3 because, in contrast to other MT isoforms, it is mainly expressed in the central nervous system and therefore is likely to be the most relevant isoform for potentially modulating HD 
phenotypes. As seen in Figure 3B, httEx1-Q97 induced significant toxicity as compared to httEx1-Q25, reducing MTS activity by ca. 25\% after 48 hours of expression. Notably, co-expression of MT3 was protective, and restored more than $50 \%$ of the MTS activity lost due to httEx1-Q97 toxicity. In parallel with reduced levels of toxicity, MT3 overexpression significantly reduced inclusion body formation (Figure 3C) and the production of SDS-insoluble material in cells expressing httEx1Q97 (Figure 3D).

\section{Discussion}

Our results show that altering levels of copper either by addition of exogenous copper, addition of a copper chelator or over-expression of copper homeostatic genes affects aggregation and/or toxicity of an aggregation-prone N-terminal fragment of htt. Copper could directly participate in HD pathogenesis by increasing aggregation of $\mathrm{htt}$ and/or by altering brain energy metabolism (e.g. LDH metabolism is altered in mouse HD brain) [4]. However, it should be noted that some of the copper-homeostatic proteins tested in yeast also regulate iron metabolism and therefore some htt toxicity modifying genes in our analysis may be linked to iron metabolism. Copper metabolism is highly regulated and, although a chelation approach with clioquinol and tetrathiomolybdate has been partly successful in reducing pathology in an HD mouse model [5, 23], a more targeted approach to restore copper homeostasis may provide further and more consistent improvement with fewer side effects, which is particularly important for long-term treatment.

MTs could provide such a missing link. In our study, two yeast MT homologs, Crs5 and Cup1-2, suppress toxicity in a yeast model of mutant htt toxicity, with Crs5 showing the most significant rescue of the genes tested. In addition, one of the mammalian homologs of this yeast gene, MT3, was also protective against htt toxicity in HeLa cells. MTs are a family of low-molecular-weight, cysteine-rich proteins which bind not only bind copper, but also zinc and heavy metals [24]. MTs are believed to have antioxidant properties due to their multiple sulfhydryl groups, which interact with ROS. Past studies have shown that MT3 over-expression protects against $\mathrm{H}_{2} \mathrm{O}_{2}$-induced oxidative stress [25]. Under stress conditions, including oxidative stress, the metal-responsive transcription factor (MTF-1) activates expression of MTs via metal-response elements (MREs) present in their promoter regions. In support of a neuroprotective effect of MTs, addition of Zn (II) to cultured neurons causes an upregulation of MTs and a correlated increase in survival of dopaminergic neurons [26]. In addition, the neuroprotective drug resveratrol (neuroprotective in HD models, [27]) was also shown to up-regulate MTs [28]. How MT3 protects against polyQ toxicity is not clear, but it is likely linked to either the copper-binding ability of this protein or its general antioxidant actions, or both. Indeed we have previously shown that expression of a mutant htt fragment is associated with an increase in cellular ROS production in both yeast and mammalian cells [20, 29], but it is unknown how increased ROS are produced. Copper could be involved in ROS production by modulating httEx1 aggregation and/or directly participate in Fenton-type reactions leading to biomolecular damage due to oxidative stress. Therefore, the metal binding and antioxidant properties of MTs make these proteins good candidates for therapeutically targeting HD, especially given the importance of oxidative stress in HD (reviewed in $[2,30]$ ) and the likely importance of copper in htt aggregation/toxicity as shown in our study and in experiments performed by Fox and colleagues [4]. This critical study 
showed that copper binds to histidine 82 and 98 in a 171 amino acid N-terminal fragment of htt. It is therefore possible that direct interactions of copper with httEx 1 (which contains histidine 82) may affect the oligomerisation properties of this protein and subsequent fibril formation and thereby impact on the production of toxic intermediate protein species. This hypothesis remains to be tested in the future using copper-binding deficient htt fragments.

In summary, we have shown that copper increases polyQ aggregation in vitro and in vivo and that overexpression of MTs protects against polyQ toxicity in two cellular HD model systems. Given the importance of MTs in Alzheimer's disease [31-35] and other chronic CNS diseases such as amyotrophic lateral sclerosis [36, 37] and Parkinson's Disease [38-43], we propose that MTs are excellent candidate therapeutic targets for HD.

\section{Acknowledgement}

The Wyttenbach lab would like to thank the Medical Research Council (MRC), Biotechnology and Biological Sciences Research Council (BBSRC), and the Gerald Kerkut Trust. Funding in the Giorgini lab is provided by CHDI Inc., Huntington's Disease Association and the MRC. 


\section{Figure legends}

Figure 1

A) Representative AFM images (scan size $10 \times 10 \mu \mathrm{m}$ ) of recombinant httEx1-Q20 or Q53 incubated for 24 hours in the presence or absence of $10 \mu \mathrm{M} \mathrm{CuCl}_{2}$. No significant aggregation was seen for httEx1-Q20, whilst fibrillar structures were evident for the httEx1-Q53 reaction and the number of fibrillar structures per $10 \mu \mathrm{m}^{2}$ area increased in the presence of $\mathrm{CuCl}_{2}$

B) Dot blot of SDS-insoluble httEx1-Q53 recombinant protein, generated using a filter trap assay, probed with the S830 anti-httEx1 antibody (kindly provided by G. Bates, King's College, London). No insoluble material was detected for httEx1-Q20 (data not shown). Incubation of httEx1-Q53 in the presence of $10 \mu \mathrm{M} \mathrm{CuCl}_{2}$ markedly increases the amount of insoluble material at all time points.

Figure 2

Parental wild-type Y258 yeast containing constructs for overexpression of the indicated yeast ORFs were transformed with $\mathrm{p} 425-\mathrm{Htt} 25 \mathrm{Q}$ or $\mathrm{p} 425-\mathrm{Htt} 103 \mathrm{Q}$ and cellular viability determined using growth assays [16]. The expression of both the huntingtin constructs and the indicated yeast ORFs is induced by galactose. Five-fold serial dilutions of stationary phase cultures starting with an equal number of cells of representative suppressor genes are shown. Expression of htt-Q103 induces significant toxicity compared to expression of htt-Q25. Overexpression of copperhomeostatic genes (see Table 1 for details) shows a significant rescue effect towards htt-Q103 toxicity (Cox23 and Ccc2 not shown). This growth assay was performed twice with identical results.

Figure 3

A) Percentage of HeLa cells expressing httEx1-Q97mRFP containing an inclusion body (IB) when left untreated or when treated with clioquinol or $\mathrm{CuCl}_{2}$ (mean, +/- SE, $\mathrm{n}=3$ ). The addition of $\mathrm{CuCl}_{2}$ significantly increases the percentage of cells containing an IB, whilst the presence of clioquinol at a concentration of $10 \mu \mathrm{M}$, causes a modest decrease in percentage of cells containing an IB.

B) MTS absorbance measured at 490nm for HeLa cells expressing httEx1Q25/Q97mRFP for 48 hours (mean +/- SE, n=3). Expression of httEx1-Q97 induced toxicity, demonstrated by a $23 \%+/-2 \%$ reduction in MTS absorbance. Coexpression of MT3 ameliorated this toxicity by $60 \%+/-5 \%$.

C) Percentage of HeLa cells expressing httEx1-Q97mRFP containing an inclusion body (IB) when transfected with an empty vector or with MT3 (mean +/- SE, n=4). Co-expression of MT3 significantly reduces the percentage of cells containing an IB. MT3 expression was verified by Western blotting (data not shown).

D) Dot blot of SDS-insoluble material extracted from HeLa cells expressing httEx1Q97mRFP protein using a filter trap assay, probed with an anti-httEx1 antibody (S830). 1x and 0.5x indicate the relative amount of pellet loaded. No insoluble 
material was detected for cells expressing httEx1-Q25 as shown previously ([14, 22], data not shown). Cells co-expressing MT3 produced significantly less SDS-insoluble material, compared to empty vector transfected control cells (quantified in right graph) (mean $+/-\mathrm{SD}, \mathrm{n}=2)$.

\section{References}

1 DiFiglia, M., Sapp, E., Chase, K. O., Davies, S. W., Bates, G. P., Vonsattel, J. P. and Aronin, N. (1997) Aggregation of Huntingtin in Neuronal Intranuclear Inclusions and Dystrophic Neurites in Brain. Science. 277, 1990-1993

2 Hands, S., Sinadinos, C. and Wyttenbach, A. (2008) Polyglutamine gene function and dysfunction in the ageing brain. Biochimica et Biophysica Acta (BBA) - Gene Regulatory Mechanisms. 1779, 507-521

3 Dexter, D. T., Carayon, A., Javoy-Agid, F., Agid, Y., Wells, F. R., Daniel, S. E., Lees, A. J., Jenner, P. and Marsden, C. D. (1991) Alterations in the levels of iron, ferritin and other trace metals in Parkinson's Disease and other neurodegenerative diseases affecting the basal ganglia. Brain. 114, 1953-1975 4 Fox, J. H., Kama, J. A., Lieberman, G., Chopra, R., Dorsey, K., Chopra, V., Volitakis, I., Cherny, R. A., Bush, A. I. and Hersch, S. (2007) Mechanisms of Copper Ion Mediated Huntington's Disease Progression. PLoS ONE. 2, e334

5 Nguyen, T., Hamby, A. and Massa, S. M. (2005) Clioquinol downregulates mutant huntingtin expression in vitro and mitigates pathology in a Huntington's disease mouse model. PNAS USA. 102, 11840-11845

6 Huang, X., Atwood, C. S., Hartshorn, M. A., Multhaup, G., Goldstein, L. E., Scarpa, R. C., Cuajungco, M. P., Gray, D. N., Lim, J., Moir, R. D., Tanzi, R. E. and Bush, A. I. (1999) The Abeta Peptide of Alzheimer's Disease Directly Produces Hydrogen Peroxide through Metal Ion Reduction. Biochemistry. 38, 7609-7616

7 Huang, X., Cuajungco, M. P., Atwood, C. S., Hartshorn, M. A., Tyndall, J. D. A., Hanson, G. R., Stokes, K. C., Leopold, M., Multhaup, G., Goldstein, L. E., Scarpa, R. C., Saunders, A. J., Lim, J., Moir, R. D., Glabe, C., Bowden, E. F., Masters, C. L., Fairlie, D. P., Tanzi, R. E. and Bush, A. I. (1999) Cu(II)

Potentiation of Alzheimer Abeta Neurotoxicity. Correlation with cell-free hydrogen peroxide production and metal reduction. J. Biol. Chem. 274, 3711137116

8 Wacker, J. L., Zareie, M. H., Fong, H., Sarikaya, M. and Muchowski, P. J. (2004) Hsp70 and Hsp40 attenuate formation of spherical and annular polyglutamine oligomers by partitioning monomer. Nat Struct Mol Biol. 11, 1215-1222

9 Ratovitski, T., Gucek, M., Jiang, H., Chighladze, E., Waldron, E., D'Ambola, J., Hou, Z., Liang, Y., Poirier, M. A., Hirschhorn, R. R., Graham, R., Hayden, M. R., Cole, R. N. and Ross, C. A. (2009) Mutant Huntingtin N-terminal Fragments of Specific Size Mediate Aggregation and Toxicity in Neuronal Cells. J. Biol. Chem. 284, 10855-10867

10 Ignatova, Z., Thakur, A. K., Wetzel, R. and Gierasch, L. M. (2007) In-cell Aggregation of a Polyglutamine-containing Chimera Is a Multistep Process Initiated by the Flanking Sequence. J. Biol. Chem. 282, 36736-36743 
11 Desai, U. A., Pallos, J., Ma, A. A. K., Stockwell, B. R., Thompson, L. M., Marsh, J. L. and Diamond, M. I. (2006) Biologically active molecules that reduce polyglutamine aggregation and toxicity. Hum. Mol. Genet. 15, 2114-2124

12 Wanker, E. E., Scherzinger, E., Heiser, V., Sittler, A., Eickhoff, H. and Lehrach, H. (1999) Membrane filter assay for detection of amyloid-like polyglutamine-containing protein aggregates. Methods Enzymol. 309, 375-386 13 Paul J. Muchowski, Schaffar, G., Sittler, A., Wanker, E. E., Hayer-Hartl, M. K. and Hartl, F. U. (2000) Hsp70 and Hsp40 chaperones can inhibit selfassembly of polyglutamine proteins into amyloid-like fibrils. PNAS USA. 97, 7841-7846

14 King, M. A., Hands, S., Hafiz, F., Mizushima, N., Tolkovsky, A. M. and Wyttenbach, A. (2008) Rapamycin Inhibits Polyglutamine Aggregation Independently of Autophagy by Reducing Protein Synthesis. Mol Pharmacol. 73, 1052-1063

15 Giorgini, F. and Muchowski, P. J. (2006) Screening for genetic modifiers of amyloid toxicity in yeast. Methods Enzymol 412, 201-222

16 Meriin, A. B., Zhang, X., He, X., Newnam, G. P., Chernoff, Y. O. and Sherman, M. Y. (2002) Huntington toxicity in yeast model depends on polyglutamine aggregation mediated by a prion-like protein Rnq1. J Cell Biol. 157, 997-1004

17 Mumberg, D., Muller, R. and Funk, M. (1994) Regulatable promoters of Saccharomyces cerevisiae: comparison of transcriptional activity and their use for heterologous expression. . Nucleic Acids Res. 22, 5767-5768

18 Legleiter, J., Lotz, G. P., Miller, J., Ko, J., Ng, C., Williams, G. L., Finkbeiner, S., Patterson, P. H. and Muchowski, P. J. (2009) Monoclonal antibodies recognize distinct conformational epitopes formed by polyglutamine in a mutant huntingtin fragment. J. Biol. Chem., M109.016923

19 Wyttenbach, A., Carmichael, J., Swartz, J., Furlong, R. A., Narain, Y., Rankin, J. and Rubinsztein, D. C. (2000) Effects of heat shock, heat shock protein 40 (HDJ-2), and proteasome inhibition on protein aggregation in cellular models of Huntington's disease. Proc.Natl.Acad.Sci.U.S.A. 97, 2898

20 Wyttenbach, A., Sauvageot, O., Carmichael, J., az-Latoud, C., Arrigo, A. P. and Rubinsztein, D. C. (2002) Heat shock protein 27 prevents cellular polyglutamine toxicity and suppresses the increase of reactive oxygen species caused by huntingtin. Hum.Mol.Genet. 11, 1137

21 Wyttenbach, A., Swartz, J., Kita, H., Thykjaer, T., Carmichael, J., Bradley, J., Brown, R., Maxwell, M., Schapira, A., Orntoft, T. F., Kato, K. and Rubinsztein, D. C. (2001) Polyglutamine expansions cause decreased CREmediated transcription and early gene expression changes prior to cell death in an inducible cell model of Huntington's disease. Hum. Mol. Genet. 10, 1829-1845 22 King, M. A., Goemans, C. G., Hafiz, F., Prehn, J. H. M., Wyttenbach, A. and Tolkovsky, A. M. (2008) Cytoplasmic Inclusions of Htt Exon1 Containing an Expanded Polyglutamine Tract Suppress Execution of Apoptosis in Sympathetic Neurons. J. Neurosci. 28, 14401-14415

23 Tallaksen-Greene, S. J., Janiszewska, A., Benton, K., Hou, G., Dick, R., Brewer, G. J. and Albin, R. L. (2009) Evaluation of tetrathiomolybdate in the R6/2 model of Huntington disease. Neuroscience Letters. 452, 60-62

24 Rigby Duncan, K. E. and Stillman, M. J. (2006) Metal-dependent protein folding: Metallation of metallothionein. Journal of Inorganic Biochemistry. 100, 2101-2107 
25 You, H. J., Oh, D.-h., Choi, C. Y., Lee, D. G., Hahm, K.-S., Moon, A. R. and Jeong, H. G. (2002) Protective effect of metallothionein-III on DNA damage in response to reactive oxygen species. Biochimica et Biophysica Acta (BBA) General Subjects. 1573, 33-38

26 Gauthier, M. A., Eibl, J. K., Crispo, J. A. and Ross, G. M. (2008) Covalent arylation of metallothionein by oxidized dopamine products: a possible mechanism for zinc-mediated enhancement of dopaminergic neuron survival. Neurotox Res. 14, 317-328

27 Parker, J. A., Arango, M., Abderrahmane, S., Lambert, E., Tourette, C., Catoire, H. and Neri, C. (2005) Resveratrol rescues mutant polyglutamine cytotoxicity in nematode and mammalian neurons. Nature Genetics. 37, 349-350 28 Yousuf, S., Atif, F., Ahmad, M., Hoda, N., Ishrat, T., Khan, B. and Islam, F. (2009) Resveratrol exerts its neuroprotective effect by modulating mitochondrial dysfunctions and associated cell death during cerebral ischemia. Brain Research. 1250, 242-253

29 Giorgini, F., Guidetti, P., Nguyen, Q. V., Bennett, S. C. and Muchowski, P. J. (2005) A genomic screen in yeast implicates kynurenine 3-monooxygenase as a therapeutic target for Huntington disease. Nature Genetics. 37, 526-531 30 Browne, S. E. and Beal, M. F. (2006) Oxidative Damage in Huntington's Disease Pathogenesis. Antioxidants \& Redox Signaling. 8, 2061

31 Hidalgo, J., Penkowa, M., Espejo, C., Martinez-Caceres, E. M., Carrasco, J., Quintana, A., Molinero, A., Florit, S., Giralt, M. and Ortega-Aznar, A. (2006) Expression of Metallothionein-I, -II, and -III in Alzheimer Disease and Animal Models of Neuroinflammation. Experimental Biology and Medicine. 231, 14501458

32 Zambenedetti, P., Giordano, R. and Zatta, P. (1998) Metallothioneins are highly expressed in astrocytes and microcapillaries in Alzheimer's disease. Journal of Chemical Neuroanatomy. 15, 21-26

33 Adlard, P. A., West, A. K. and Vickers, J. C. (1998) Increased Density of Metallothionein I/II-Immunopositive Cortical Glial Cells in the Early Stages of Alzheimer's Disease. Neurobiology of Disease. 5, 349-356

34 Uchida, Y., Takio, K., Titani, K., Ihara, Y. and Tomonaga, M. (1991) The growth inhibitory factor that is deficient in the Alzheimer's disease brain is a 68 amino acid metallothionein-like protein. Neuron. 7, 337-347

35 Tsuji, S., Kobayashi, H., Uchida, Y., Ihara, Y. and Miyatake, T. (1992)

Molecular cloning of human growth inhibitory factor cDNA and its downregulation in Alzheimer's disease. EMBO J. 11, 4843-4850

36 Tokuda, E., Ono, S.-I., Ishige, K., Naganuma, A., Ito, Y. and Suzuki, T. (2007) Metallothionein proteins expression, copper and zinc concentrations, and lipid peroxidation level in a rodent model for amyotrophic lateral sclerosis. Toxicology. 229, 33-41

37 Roos, P. M., Vesterberg, O. and Nordberg, M. (2006) Metals in Motor Neuron Diseases. Experimental Biology and Medicine. 231, 1481-1487 38 Hwang, Y. P., Kim, H. G., Han, E. H. and Jeong, H. G. (2008) Metallothionein-III protects against 6-hydroxydopamine-induced oxidative stress by increasing expression of heme oxygenase-1 in a PI3K and ERK/Nrf2dependent manner. Toxicology and Applied Pharmacology. 231, 318-327

39 Miyazaki, I., Asanuma, M., Hozumi, H., Miyoshi, K. and Sogawa, N. (2007) Protective effects of metallothionein against dopamine quinone-induced dopaminergic neurotoxicity. FEBS Letters. 581, 5003-5008 
40 Ebadi, M., Brown-Borg, H., El Refaey, H., Singh, B. B., Garrett, S., Shavali, S. and Sharma, S. K. (2005) Metallothionein-mediated neuroprotection in genetically engineered mouse models of Parkinson's disease. Molecular Brain Research. 134, 67-75

41 Ebadi, M. and Sharma, S. (2006) Metallothioneins 1 and 2 Attenuate Peroxynitrite-Induced Oxidative Stress in Parkinson Disease. Experimental Biology and Medicine. 231, 1576-1583

42 Rojas, P., Hidalgo, J., Ebadi, M. and Rios, C. (2000) Changes of Metallothionein I + II Proteins in the Brain after 1-Methyl-4-Phenylpyridinium Administration in Mice. Progress in Neuro-Psychopharmacology and Biological Psychiatry. 24, 143-154

43 Shiraga, H., Pfeiffer, R. F. and Ebadi, M. (1993) The effects of 6hydroxydopamine and oxidative stress on the level of brain metallothionein. Neurochem Int. 23, 561-566

44 Hodges, A., Strand, A. D., Aragaki, A. K., Kuhn, A., Sengstag, T., Hughes, G., Elliston, L. A., Hartog, C., Goldstein, D. R., Thu, D., Hollingsworth, Z. R., Collin, F., Synek, B., Holmans, P. A., Young, A. B., Wexler, N. S., Delorenzi, M., Kooperberg, C., Augood, S. J., Faull, R. L. M., Olson, J. M., Jones, L. and Luthi-Carter, R. (2006) Regional and cellular gene expression changes in human Huntington's disease brain. Hum. Mol. Genet. 15, 965-977 45 A. Hodges, Hughes, G., Brooks, S., Elliston, L., Holmans, P., Dunnett, S. B. and Jones, L. (2008) Brain gene expression correlates with changes in behavior in the R6/1 mouse model of Huntington's disease. Genes, Brain and Behavior. 7, 288-299

46 Morton, A. J., Hunt, M. J., Hodges, A. K., Lewis, P. D., Redfern, A. J., Dunnett, S. B. and Jones, L. (2005) A combination drug therapy improves cognition and reverses gene expression changes in a mouse model of Huntington's disease. European Journal of Neuroscience. 21, 855-870

47 Runne, H., Regulier, E., Kuhn, A., Zala, D., Gokce, O., Perrin, V., Sick, B., Aebischer, P., Deglon, N. and Luthi-Carter, R. (2008) Dysregulation of Gene Expression in Primary Neuron Models of Huntington's Disease Shows That Polyglutamine-Related Effects on the Striatal Transcriptome May Not Be Dependent on Brain Circuitry. J. Neurosci. 28, 9723-9731 
Table 1. Yeast and mammalian homologs of copper binding proteins. Altered expression in HD models and/or effects on toxicity in a yeast model of HD are indicated (these data were compiled form seven studies including this one).

\begin{tabular}{|c|c|c|c|c|}
\hline $\begin{array}{l}\text { Mammalian } \\
\text { homolog }\end{array}$ & $\begin{array}{l}\text { Expression } \\
\text { changes in HD } \\
\text { models }\end{array}$ & Function & $\begin{array}{l}\text { Yeast } \\
\text { homolog }\end{array}$ & $\begin{array}{l}\text { Effect on } \\
\text { httEx1 } \\
\text { toxicity in } \\
\text { yeast model }\end{array}$ \\
\hline $\begin{array}{l}\text { Metallothionein } \\
1 / 2 \text { (MT1) }\end{array}$ & $\begin{array}{l}\text { mRNA } \\
\text { upregulated (5- } \\
\text { fold) in PC12 } \\
\text { cells, Tet-On } \\
\text { Q74 [21] and in } \\
\text { HD human } \\
\text { brain [44] }\end{array}$ & $\begin{array}{l}\text { Metal donation to } \\
\text { target } \\
\text { apometalloproteins } \\
\text { (particularly zinc finger } \\
\text { proteins and enzymes), } \\
\text { metal detoxification, } \\
\text { and antioxidant }\end{array}$ & $\begin{array}{l}\text { Crs5 } \\
\text { Cup1-2 }\end{array}$ & $\begin{array}{l}\text { Rescues } \\
\text { Rescues }\end{array}$ \\
\hline \multicolumn{5}{|l|}{$\begin{array}{l}\text { Metallothionein } \\
3 \text { (MT3) }\end{array}$} \\
\hline $\mathrm{CCS}$ & & $\begin{array}{l}\text { Transports } \mathrm{Cu} \text { to } \mathrm{CuZn} \\
\text { SOD. }\end{array}$ & Lys-7 & Rescues \\
\hline Atox 1 & & $\begin{array}{l}\text { Delivers copper to } \\
\text { copper-binding domain } \\
\text { of MNK/WND. } \\
\text { Protects neurons } \\
\text { against oxidative stress } \\
\text { and serum starvation. }\end{array}$ & Atx1 & Rescues \\
\hline \multirow[t]{2}{*}{ Cox17 } & & $\begin{array}{l}\text { Delivers } \mathrm{Cu} \text { to cyt } \mathrm{c} \\
\text { oxidase in } \\
\text { mitochondria, required } \\
\text { for functional } \\
\text { expression of cytc } \\
\text { oxidase }\end{array}$ & Cox 17 & Rescues \\
\hline & & & Cox23 & $\begin{array}{l}\text { Rescues } \\
\text { (not shown) }\end{array}$ \\
\hline ATP7A (MNK) & & $\begin{array}{l}\text { Copper-translocating } \\
\text { P-type ATPase. } \\
\text { Delivers copper to } \\
\text { cuproenzymes in the } \\
\text { Golgi compartment and } \\
\text { effluxes excess copper }\end{array}$ & Ccc2 & \multirow[t]{2}{*}{$\begin{array}{l}\text { Rescues } \\
\text { (not shown) }\end{array}$} \\
\hline ATP7B (WND) & $\begin{array}{l}\text { Protein } \\
\text { upregulated in } \\
\text { R6/2 mice [4] }\end{array}$ & $\begin{array}{l}\text { Functions within the } \\
\text { secretory apparatus, } \\
\text { loading cytoplasmic } \\
\text { copper onto the plasma } \\
\text { ferroxidase } \\
\text { ceruloplasmin, } \\
\text { (facilitates iron export) }\end{array}$ & & \\
\hline Ceruloplasmin & $\begin{array}{l}\text { mRNA } \\
\text { upregulated in } \\
\text { striatal primary } \\
\text { neurons } \\
\text { (httN171Q82), } \\
\text { R6/1, R6/2 mice } \\
\text { and HD human } \\
\text { brain [44-47] }\end{array}$ & $\begin{array}{l}\text { Copper storage, iron } \\
\text { metabolism }\end{array}$ & Fet3 & Not tested \\
\hline $\begin{array}{l}\text { DMT1 } \\
\text { (Nramp2) }\end{array}$ & & $\begin{array}{l}\text { Non-specific divalent } \\
\text { cation transporter } \\
\text { (import) - iron } \\
\text { (contains IRE) and } \\
\text { copper }\end{array}$ & $\begin{array}{l}\text { Smf1, } \\
\text { Smf2, and } \\
\text { Smf3 }\end{array}$ & Not tested \\
\hline
\end{tabular}


HttEx1 Q20

HttEx1 Q53
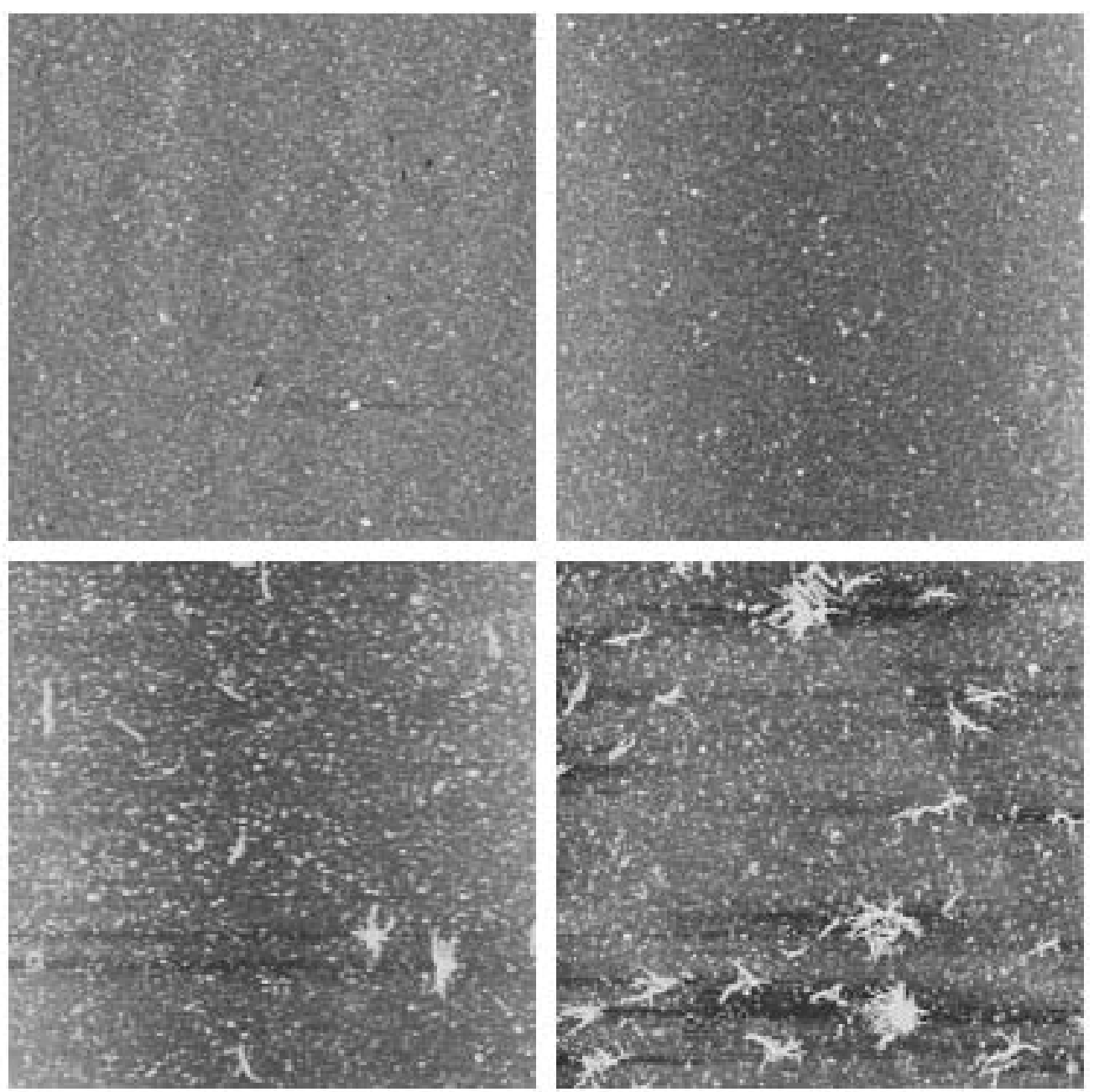

B

Incubation time (hours)

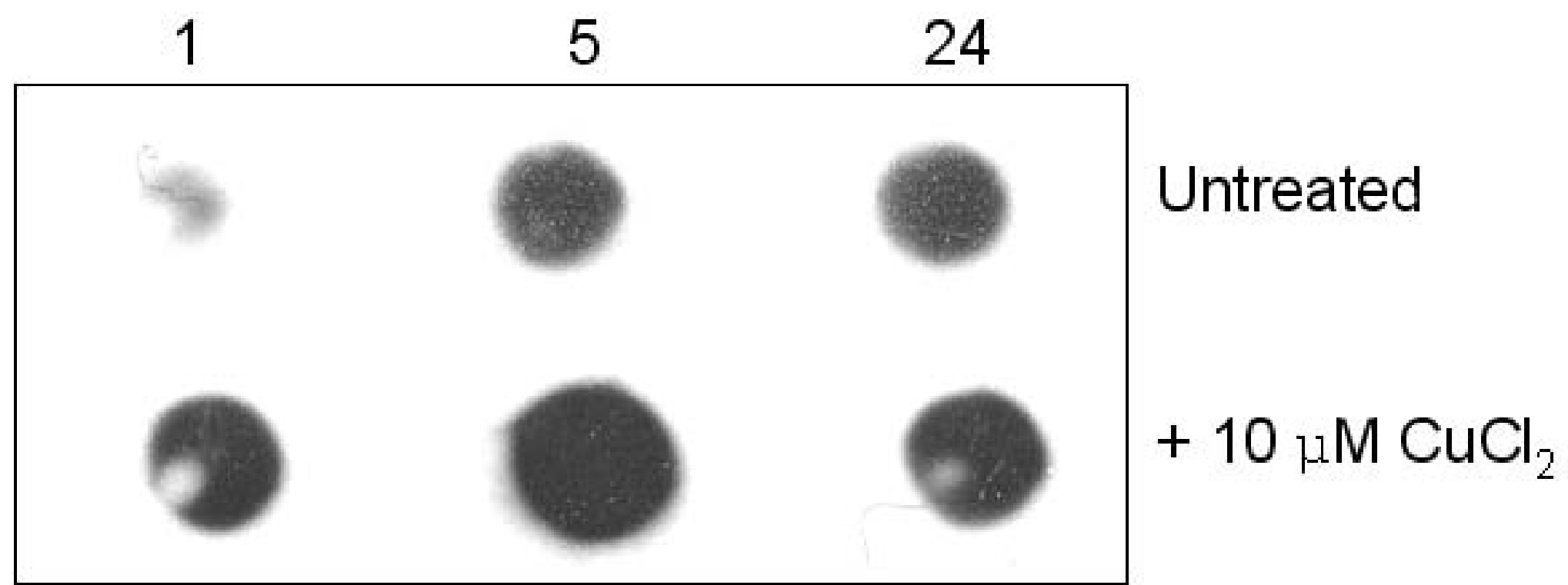



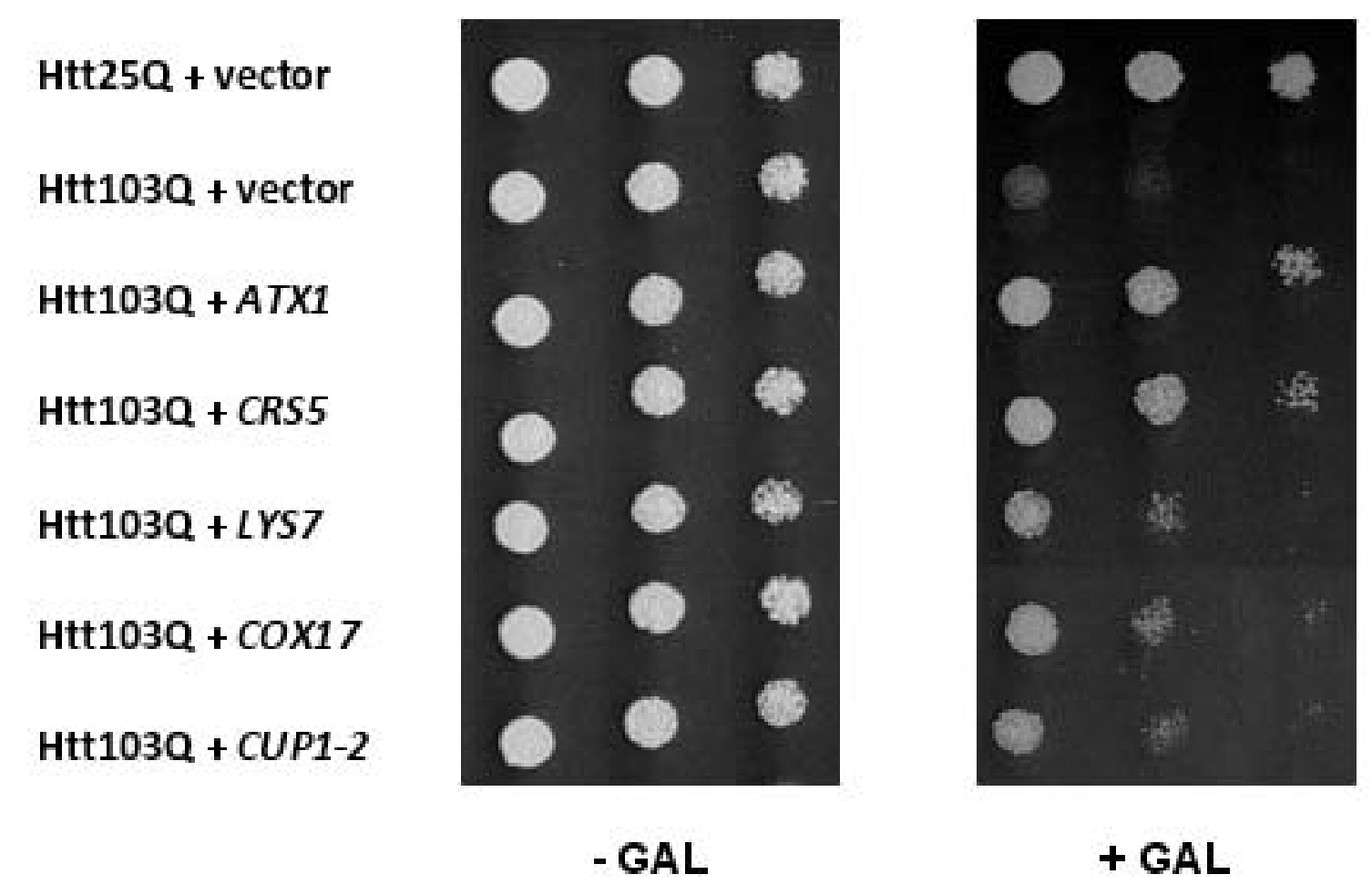

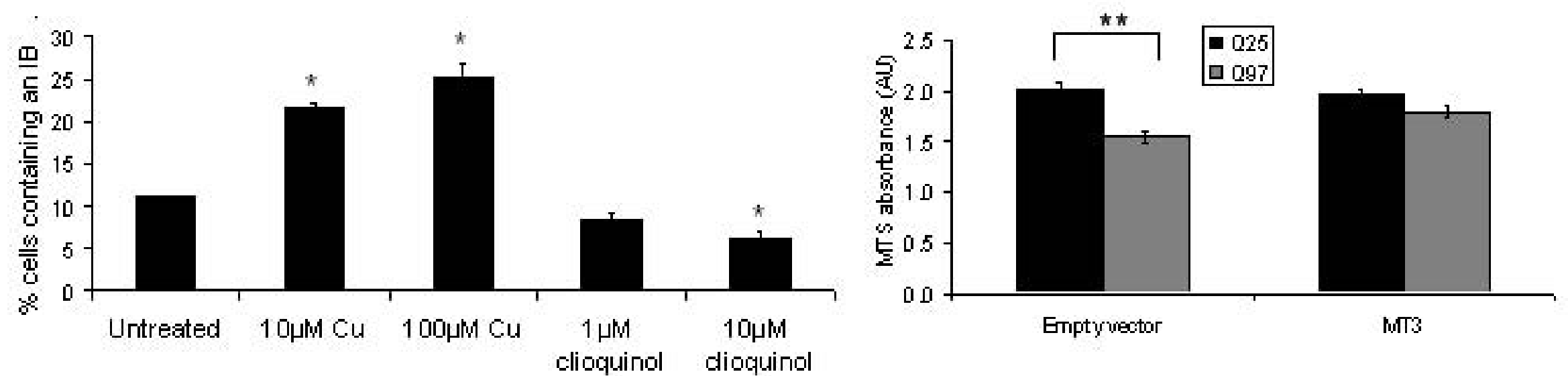

C

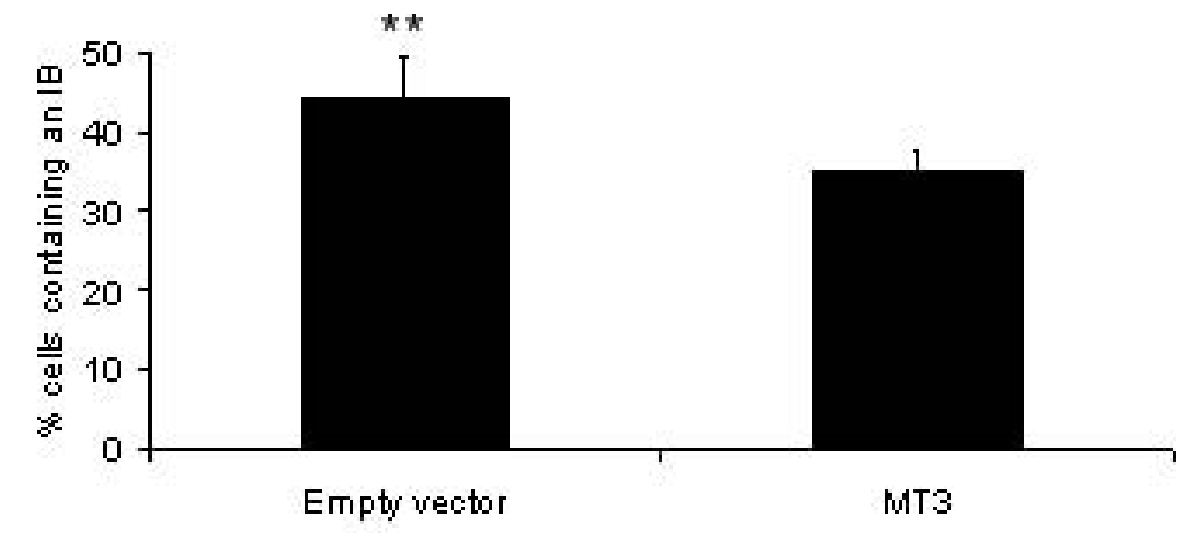

C

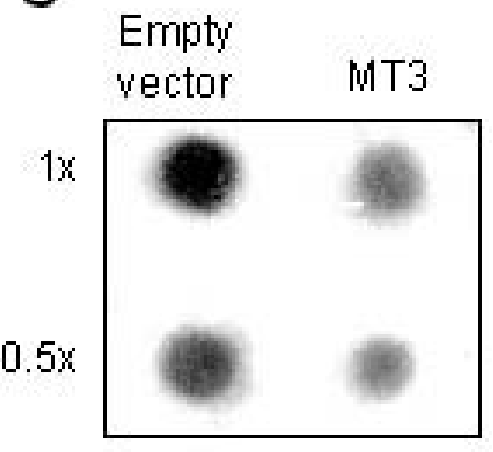

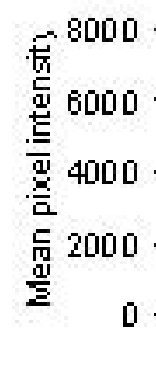

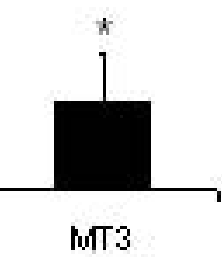

